\title{
Responsivity of Pituitary Gonadotropes to Luteinizing Hormone-releasing Factor in Idiopathic Precocious Puberty, Precocious Thelarche, Precocious Adrenarche, and in Patients Treated with Medroxyprogesterone Acetate
}

\author{
EDWARD O. REITER, SELNA L. KAPLAN, FELIX A. CONTE, AND \\ MELVIN M. GRUMBACH ${ }^{(45)}$ \\ Department of Pediatrics, University of California at San Francisco, San Francisco, California, USA
}

\section{Extract}

One hundred micrograms synthetic luteinizing hormonereleasing factor (LRF) were administered to 13 girls and 2 boys with idiopathic precocious puberty, 3 girls with precocious thelarche, 2 girls with precocious adrenarche, and 5 children treated with medroxyprogesterone acetate (MPA). Luteinizing hormone (LH), follicle-stimulating hormone (FSH), and sex steroid responses were assessed.

The mean readily releasable $\mathrm{LH}$ rose to a peak of $8.4 \pm 1.8$ $\mathrm{ng} / \mathrm{ml}$ (LER 960) in the children with idiopathic precocious puberty and was significantly greater than in normal prepubertal $(1.8 \pm 0.14)$ or pubertal children $(4.9 \pm 0.34)$. The peak plasma FSH response $(8.4 \pm 1.4 \mathrm{ng} / \mathrm{ml})($ LER 869$)$ was higher in precocious puberty but not significantly greater than in normal prepubertal $(5.3 \pm 1.9)$ or pubertal girls $(6.0 \pm 1.2)$. The mean concentration of plasma estradiol rose significantly above resting levels after LRF in the girls with idiopathic precocious puberty. The LH response in girls with precocious thelarche and adrenarche was in the prepubertal range. In 4 of 5 children with sexual precocity treated with MPA, the LH release evoked by LRF was diminished.

\section{Speculation}

Premature neural activation of hypothalamic LRF synthesis and release may occur in children with idiopathic precocious puberty. This leads to increased pituitary gonadotropin synthesis, storage, and more readily releasable $\mathrm{LH}$. The higher FSH release after LRF in normal girls than boys may be a factor in the strikingly higher prevalence of idiopathic precocious puberty in girls than in boys.

An important advance in our understanding of central nervous system regulation of pituitary gonadotropin secretion stems from the isolation and synthesis of LRF. This hypothalamic hypophysiotropic hormone induces the release of both pituitary LH and FSH $(4,35)$. Recent studies have demonstrated that LRF evokes a substantially greater rise in plasma LH in normal pubertal than in normal prepubertal children $(13,15,33,34)$. We have suggested that this increase in pituitary readily releasable $\mathrm{LH}$ at puberty is secondary to increased production of endogenous hypothalamic LRF consequent to decreased sensitivity of the steroid negativefeedback gonadostat $(13,34)$.

In children with idiopathic precocious puberty, central nervous system activation of the pituitary-gonadal system occurs prematurely. For poorly understood reasons, endogenous secretion of LRF may increase earlier than normal and lead to greater pituitary gonadotropin storage and secretion. To examine this hypothesis, we have administered synthetic LRF to 15 children with idiopathic precocious puberty and assessed the readily releasable pituitary gonadotropins by the change in concentration of plasma FSH and LH. The data demonstrate that the pattern of pituitary gonadotropin release correlates with precocious sexual maturation rather than chronologic age.

\section{MATERIALS AND METHODS}

The pertinent clinical findings in the 13 girls and 2 boys with idiopathic precocious puberty are indicated in Table 1 . Pubertal staging of the patients was based on the criteria of Marshall and Tanner $(24,25)$. Three of these 15 children were studied before and during therapy with MPA. Additionally, one boy $(J P)$, with congenital virilizing adrenal hyperplasia and true precocious puberty (reported in detail elsewhere (28)), was given LRF before and during therapy; and one girl (JS), who had received MPA therapy for 1 year at the time of her first LRF test, was retested 6 months after cessation of treatment. Three other girls with precocious thelarche and two with precocious adrenarche were also evaluated. Written informed parental consent was always obtained. No ill effects were observed after LRF administration.

The LRF was synthesized by Dr. J. Rivier and kindly supplied by Dr. R. Guillemin of the Salk Institute, La Jolla, California. This preparation was characterized and prepared especially for clinical studies as described previously $(1,26)$. LRF at the concentration of $200 \mu \mathrm{g} / \mathrm{ml}$ distilled water containing $5 \mathrm{mg} / \mathrm{ml}$ human serum albumin was sterilized by 
passage through a $0.45-\mu$ Millipore filter using a Sweeny adaptor. All of the patients were given $100 \mu \mathrm{g} \mathrm{LRF}$ as a single intravenous injection after an overnight fast. Blood samples for determination of plasma $\mathrm{LH}$ and FSH were collected at 0,5 , $10,15,30,60,120,180$, and $240 \mathrm{~min}$ after the administration of LRF. Plasma estradiol and testosterone were determined in the 0 and 240 min samples.

Plasma LH and FSH concentrations were measured by double antibody radioimmunoassay $(6,38)$ using the highly purified pituitary reference preparations LER 960 (LH) and LER 869 (FSH) for iodination and dose interpolation. In our laboratory, $1 \mathrm{ng}$ plasma LH LER 960 and $1 \mathrm{ng}$ plasma FSH LER 869 are equivalent, respectively, to $40 \mathrm{ng}$ and $100 \mathrm{ng}$ of the human pituitary standard LER 907. The intra-assay coefficient of variation is $10 \%$ for $\mathrm{LH}$ values between 1 and 4 $\mathrm{ng} / \mathrm{ml}$ and $7.6 \%$ between 4 and $10 \mathrm{ng} / \mathrm{ml}$; for $\mathrm{FSH}$ values between 1 and $12 \mathrm{ng} / \mathrm{ml}$, it is $13.4 \%$. Plasma estradiol, estrone, testosterone, and 17-hydroxyprogesterone were measured by radioimmunoassay, as described previously $(14,33)$.

Plasma LH and FSH after the LRF injection were analyzed as to the peak rise attained, the maximum increment over basal values and the area circumscribed by the 4-hr curve of gonadotropin concentration above the basal concentration. These results were compared with those obtained in this laboratory in 18 normal prepubertal and 34 pubertal children. Statistical analyses were performed by using the unpaired Student $t$ test for gonadotropin data and the paired Student $t$ test for evaluating the steroid data.

\section{RESULTS}

\section{CHILDREN WITH PRECOCIOUS PUBERTY (TABLES 2, 3)}

$L H$. The mean basal levels, peak response, maximal increment over basal, and the integrated area were all significantly greater in the children with precocious puberty than in normal prepubertal children. The mean peak response of LH, maximal increment, and integrated area values were also higher in the children with precocious puberty than in normal prepubertal children. The readily releasable $\mathrm{LH}$ in the children with idiopathic precocious puberty did not correlate with chronologic age or bone age, or age at onset of puberty, stage of pubertal development, or endogenous gonadal steroid levels. As there is no sex specificity in release of LH after 100 $\mu \mathrm{g}$ synthetic LRF $(13,34)$ (Table 2 ), plasma LH responses in the children with idiopathic precocious puberty were compared with those of normal girls and boys (Table 3 ).

$F S H$. Although the mean values for peak response for the maximal increment over basal levels and for the integrated area of plasma FSH values after the intravenous bolus of LRF were greater in the girls with idiopathic precocious puberty than in normal prepubertal and premenarchal pubertal girls, the differences were not significant. Pubertal and prepubertal girls had significantly higher levels of readily releasable FSH after LRF than prepubertal or pubertal boys at all doses tested (13, 34). Therefore, the FSH data from the girls with precocious puberty were compared with those in normal girls, rather than with those in girls and boys as for plasma $\mathrm{LH}$.

Estradiol and Testosterone. During the 4-hr period after the LRF infusion, plasma estradiol in 12 girls with idiopathic precocious puberty (Fig. 1) rose from $26 \pm 6.5$ (SE) $\mathrm{pg} / \mathrm{ml}$ to $39.8 \pm 10.3 \mathrm{pg} / \mathrm{ml}(P<0.02)$. In six girls who had higher basal levels $(35 \pm 10.9 \mathrm{pg} / \mathrm{ml})$, plasma estradiol increased more strikingly to $62.7 \pm 14.8 \mathrm{pg} / \mathrm{ml}(P<0.002)$. In these six girls, the peak plasma $\mathrm{LH}$ concentration $(10.7 \pm 3.2 \mathrm{ng} / \mathrm{ml})$ was not significantly greater than in the other six girls in whom plasma estradiol was measured $(6.5 \pm 3.2 \mathrm{ng} / \mathrm{ml})$. In three girls with basal plasma estradiol levels of less than $10 \mathrm{pg} / \mathrm{ml}$, no rise in gonadal steroid occurred after LRF.

In the two boys with precocious puberty, one $(S M)$ had no change in plasma testosterone $(385-375 \mathrm{ng} / 100 \mathrm{ml})$ but one $(M C)$ had an increase from 195 to $258 \mathrm{ng} / 100 \mathrm{ml}$. These findings may be compared with the significant increases $(P<$ $0.001)$ after LRF in 18 pubertal boys $(132 \pm 24$ to $184 \pm 31$ $\mathrm{ng} / 100 \mathrm{ml})$ and 10 adult males $(495 \pm 40$ to $627 \pm 36 \mathrm{ng} / 100$ ml) $(P<0.002)$ studied previously $(33)$.

\section{CHILDREN WITH INCOMPLETE SEXUAL PRECOCITY (TABLE 4)}

LH release after administration of LRF in three girls with precocious thelarche and in two with precocious adrenarche did not differ significantly from that observed in prepubertal children, which suggests that the pituitary gonadotropic reserve of $\mathrm{LH}$ in these individuals was not prematurely

Table 1. Clinical data on children with idiopathic precocious puberty

\begin{tabular}{|c|c|c|c|c|c|c|c|c|c|}
\hline \multirow[b]{2}{*}{ Patients } & \multicolumn{4}{|c|}{ Age, yr } & \multicolumn{3}{|c|}{ Pubertal stage } & \multicolumn{2}{|c|}{ Steroid } \\
\hline & Onset, yr & DX & $\mathrm{CA}$ & BA & Genital & Breast & Pubic hair & Testosterone, $\mathrm{ng} / \mathrm{ml}$ & Estradiol, $\mathrm{pg} / \mathrm{ml}$ \\
\hline \multicolumn{10}{|l|}{ Males } \\
\hline$S M$ & $4 / 12$ & $1-1 / 12$ & $1-1 / 2$ & 2 & III & & II & 385 & \\
\hline$M C$ & $5-8 / 12$ & $5-10 / 12$ & $7-6 / 12$ & $12-6 / 12$ & III & & IV & 195 & \\
\hline \multicolumn{10}{|l|}{ Females } \\
\hline$D S$ & 1 & $2-5 / 12$ & $2-5 / 12$ & $2-6 / 12$ & & II & II & & $<5(6)^{1}$ \\
\hline$R S$ & $3-9 / 12$ & $3-11 / 12$ & $3-11 / 12$ & $7-10 / 12$ & & II & III & & $<10(10)^{\mathrm{I}}$ \\
\hline$E C$ & 4 & $4-3 / 12$ & $4-10 / 12$ & $6-10 / 12$ & & III & II & & 25 \\
\hline$M G$ & 4 & 7 & $7-8 / 12$ & $8-10 / 12$ & & III & II & & 9 \\
\hline$K M$ & 4 & $6-7 / 12$ & $7-6 / 12$ & $10-6 / 12$ & & III & II & & 59 \\
\hline$K F$ & $4-5 / 12$ & $5-1 / 12$ & $5-4 / 12$ & 10 & & II & II & & 75 \\
\hline $\mathrm{CH}$ & $5-4 / 12$ & $5-10 / 12$ & $5-11 / 12$ & $8-4 / 12$ & & III & II & & 45 \\
\hline$L B$ & $5-11 / 12$ & 6 & $6-7 / 12$ & $8-10 / 12$ & & III & I & & 15 \\
\hline$E H$ & 6 & 7 & 7 & $8-6 / 12$ & & II & II & & 26 \\
\hline$M M$ & $6-5 / 12$ & $6-7 / 12$ & $6-7 / 12$ & $8-6 / 12$ & & III & I & & $(12)^{1}$ \\
\hline$S G$ & $6-6 / 12$ & $8-2 / 12$ & $8-2 / 12$ & 11 & & III & II & & $<7$ \\
\hline$E G$ & 7 & $7-10 / 12$ & $7-10 / 12$ & 10 & & II & III & & 31 \\
\hline$M S$ & $7-2 / 12$ & $7-6 / 12$ & $7-8 / 12$ & $7-8 / 12$ & & IV & III & & $10(30,32)^{1}$ \\
\hline
\end{tabular}

${ }^{1}$ Values obtained at the time of evaluation, but not during the luteinizing hormone-releasing factor (LRF) test; the other steroid data refer to the zero time sample of the LRF test. DX: age at diagnosis; CA: chronologic age at the time of the LRF test; BA: bone age at the time of the LRF test. 
Table 2. Gonadotropin results after luteinizing hormone-releasing factor (LRF) infusions in children with precocious puberty ${ }^{1}$

\begin{tabular}{|c|c|c|c|c|c|c|c|c|}
\hline \multirow[b]{2}{*}{ Patients } & \multicolumn{4}{|c|}{ LH (LER 960), ng/ml ${ }^{2}$} & \multicolumn{4}{|c|}{ FSH (LER 869), ng/ml² } \\
\hline & Basal & Peak & $\begin{array}{l}\text { Maximum } \\
\text { increment }\end{array}$ & $\begin{array}{l}\text { Área, } \\
\text { units }\end{array}$ & Basal & Peak & $\begin{array}{l}\text { Maximum } \\
\text { increment }\end{array}$ & $\begin{array}{l}\text { Area, } \\
\text { units }\end{array}$ \\
\hline \multicolumn{9}{|l|}{ Males } \\
\hline$S M$ & 1.9 & 8.4 & 6.5 & 1,000 & 1.3 & 1.8 & 0.5 & 60 \\
\hline$D C$ & 4.5 & 8.2 & 3.7 & 298 & 4.5 & 5.3 & 0.8 & 133 \\
\hline Normal $^{3}$ & 0.76 & 1.74 & 0.92 & 107 & 1.18 & 2.89 & 1.83 & 2357 \\
\hline$\left[\begin{array}{l}\text { Prepubertal } \\
(\mathrm{n}=13)\end{array}\right.$ & $\pm 0.07^{1}$ & \pm 0.15 & \pm 0.11 & \pm 19 & \pm 0.21 & \pm 0.40 & \pm 0.41 & \pm 23 \\
\hline Normal & 1.34 & 5.01 & 3.7 & 409 & 1.69 & 2.58 & 0.99 & $169]$ \\
\hline$\left[\begin{array}{l}\text { Pubertal } \\
(n=25)\end{array}\right.$ & \pm 0.11 & \pm 0.36 & \pm 0.34 & \pm 37 & \pm 0.11 & \pm 0.18 & \pm 0.12 & $\pm 27]$ \\
\hline \multicolumn{9}{|l|}{ Females } \\
\hline$D S$ & 1.3 & 3.4 & 2.1 & 301 & 1.6 & 19.5 & 17.9 & 534 \\
\hline$R S$ & 1.7 & 3.6 & 1.9 & 277 & 1.4 & 6.4 & 5.0 & 1,010 \\
\hline$E C$ & 0.7 & 22.6 & 21.9 & 2,760 & 3.5 & 18.4 & 14.9 & 2,649 \\
\hline$M G$ & 1.0 & 2.2 & 1.2 & 162 & 0.6 & 4.0 & 3.4 & 521 \\
\hline$K M$ & 1.7 & 14.8 & 13.1 & 1,903 & 1.1 & 3.5 & 2.4 & 480 \\
\hline$K F$ & 1.4 & 6.6 & 5.2 & 414 & 2.9 & 6.4 & 3.5 & 324 \\
\hline $\mathrm{CH}$ & 0.7 & 4.6 & 3.9 & 289 & 4.8 & 6.8 & 2.0 & 145 \\
\hline$L B$ & 1.8 & 2.6 & 0.8 & 107 & 0.8 & 3.4 & 2.6 & 423 \\
\hline$E H$ & 1.1 & 3.8 & 2.7 & 230 & 2.4 & 5.8 & 3.4 & 672 \\
\hline$M M$ & 0.5 & 5.9 & 5.4 & 594 & 1.1 & 3.5 & 2.4 & 480 \\
\hline$S G$ & 0.9 & 2.0 & 1.1 & 130 & 0.8 & 5.2 & 4.4 & 734 \\
\hline$E G$ & 1.3 & 23 & 21.7 & 1,047 & 1.7 & 9.5 & 7.8 & 1,369 \\
\hline$M S$ & 2.1 & 13.5 & 11.4 & 1,034 & 0.6 & 9.8 & 9.2 & 1,598 \\
\hline [Normal & 0.81 & 1.82 & 0.94 & 121 & 1.43 & 5.26 & 3.92 & 638 \\
\hline$\left[\begin{array}{l}\text { Prepubertal } \\
(\mathrm{n}=5)\end{array}\right.$ & \pm 0.15 & \pm 0.36 & \pm 0.19 & \pm 29 & \pm 0.21 & \pm 1.87 & \pm 2.01 & \pm 295 \\
\hline Normal & 1.74 & 4.72 & 2.72 & 327.2 & 2.76 & 6.0 & 3.56 & 4127 \\
\hline$\left[\begin{array}{l}\text { Pubertal } \\
(\mathrm{n}=9)\end{array}\right.$ & \pm 0.25 & \pm 0.87 & \pm 0.56 & \pm 88.3 & \pm 0.34 & \pm 1.18 & \pm 1.19 & \pm 68 \\
\hline
\end{tabular}

${ }^{1} \mathrm{LH}$ : luteinizing hormone.

${ }^{2}$ Mean \pm SEM.

${ }^{3}$ Brackets indicate normal values.

Table 3. Plasma luteinizing hormone (LH) in males and females and plasma follicle-stimulating hormone (FSH) in females after luteinizing hormone-releasing hormone

\begin{tabular}{|c|c|c|c|c|}
\hline & Basal, ng/ml & Peak, ng/ml & Maximum increment, $\mathrm{ng} / \mathrm{ml}$ & Area, units \\
\hline \multicolumn{5}{|l|}{ LH, females and males } \\
\hline $\begin{array}{l}\text { Prepubertal } \\
n=18\end{array}$ & $\begin{array}{c}0.79 \pm 0.07 \\
P<0.001\end{array}$ & $\begin{array}{l}1.76 \pm 0.14 \\
P<0.0005\end{array}$ & $\begin{array}{l}0.93 \pm 0.09 \\
P<0.002\end{array}$ & $\begin{array}{c}111.1 \pm 15.6 \\
P<0.003\end{array}$ \\
\hline $\begin{array}{l}\text { Precocious puberty } \\
\quad \mathrm{n}=15\end{array}$ & $\begin{array}{c}1.51 \pm 0.25 \\
\mathrm{NS}^{1}\end{array}$ & $\begin{array}{c}8.35 \pm 1.81 \\
P<0.015\end{array}$ & $\begin{array}{l}6.84 \pm 1.82 \\
P<0.015\end{array}$ & $\begin{array}{c}704.0 \pm 194.7 \\
P<0.03\end{array}$ \\
\hline Pubertal & $1.42 \pm 0.11$ & $4.94 \pm 0.34$ & $3.44 \pm 0.30$ & $387.2 \pm 35.7$ \\
\hline \multicolumn{5}{|l|}{ FSH, females } \\
\hline $\begin{array}{l}\text { Prepubertal } \\
\quad \mathrm{n}=5\end{array}$ & $\begin{array}{c}1.43 \pm 0.21 \\
\mathrm{NS}\end{array}$ & $\begin{array}{c}5.26 \pm 1.87 \\
\mathrm{NS}\end{array}$ & $\begin{array}{c}3.92 \pm 2.0 \\
\text { NS }\end{array}$ & $\begin{array}{c}637.6 \pm 295.0 \\
\text { NS }\end{array}$ \\
\hline $\begin{array}{l}\text { Precocious Puberty } \\
n=13\end{array}$ & $\begin{array}{c}1.81 \pm 0.35 \\
\mathrm{NS}\end{array}$ & $\begin{array}{c}8.36 \pm 1.44 \\
\mathrm{NS}\end{array}$ & $\begin{array}{c}6.55 \pm 1.39 \\
\mathrm{NS}\end{array}$ & $\begin{array}{c}837.4 \pm 190.5 \\
\text { NS }\end{array}$ \\
\hline $\begin{array}{l}\text { Pubertal } \\
n=9\end{array}$ & $2.76 \pm 0.34$ & $6.0 \pm 1.18$ & $3.56 \pm 1.19$ & $412.0 \pm 67.6$ \\
\hline
\end{tabular}

\footnotetext{
${ }^{1}$ NS: not significant.
}

increased. On the other hand, the mean peak FSH release $(13.8 \pm 2.5 \mathrm{ng} / \mathrm{ml})$ in the girls with precocious thelarche was greater than in prepubertal $(P<0.02)$ and pubertal $(P<$ $0.025)$ girls; also the area response curve $(1,585.3 \pm 309.1$ units) was significantly greater $(P<0.001)$ than in pubertal girls.

\section{MPA-TREATED CHILDREN (TABLE 5)}

Both boys ( $S M, J P$ ) given LRF during MPA treatment had lower readily releasable $\mathrm{LH}$ and $\mathrm{FSH}$, especially when assessed by the area response, as well as decreased basal plasma testosterone values. Two of the three girls studied had lower 


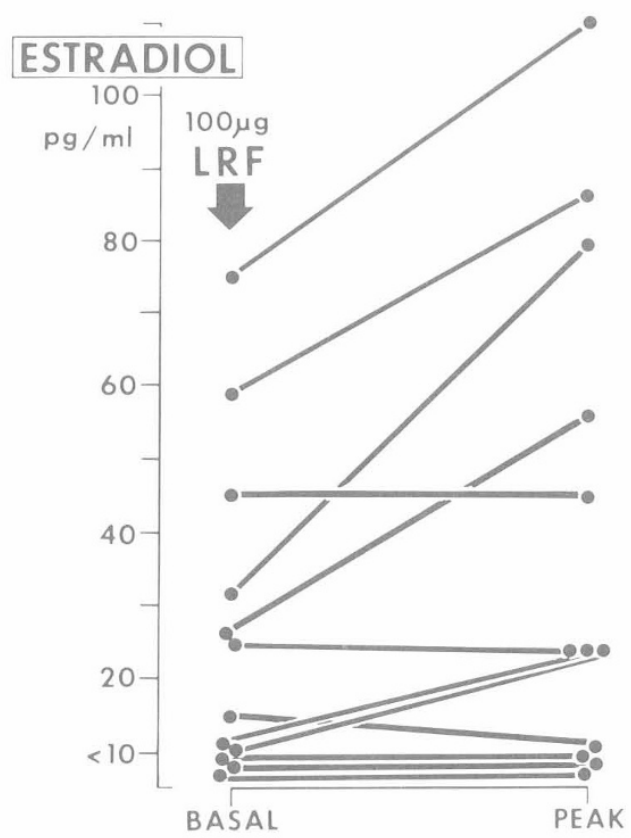

Fig. 1. The change in plasma estradiol concentration after $100 \mu \mathrm{g}$ synthetic luteinizing hormone-releasing factor $(L R F)$ in 12 girls with idiopathic precocious puberty.

pituitary LH release while on therapy. Basal levels of estradiol in plasma were diminished in two of the three girls. Readily releasable FSH, however, was not lowered by treatment with MPA in the three girls.

\section{DISCUSSION}

These data demonstrate that LRF-evoked readily releasable pituitary LH in children with idiopathic precocious puberty is significantly greater than in both normal prepubertal and pubertal children. Our data are similar in part to those of Job et al. (16) who reported pituitary LH reserve in the pubertal range in children with precocious puberty. Although pituitary FSH reserve, as assessed by a single injection of LRF, is not significantly greater in the children with precocious puberty, their generally higher responses suggest that readily releasable pituitary FSH may be increased. The larger dose $/ \mathrm{kg}$ of LRF in the younger children with precocious puberty, when compared with normal pubertal children, may partially explain the greater quantity of pituitary gonadotropin release.
Previous studies have shown that $\mathrm{LH}$ release after synthetic LRF is age dependent and increases strikingly at puberty, and further in adult males $(13,33,34)$ : This heightened pituitary LH secretory reserve may be related to increased endogenous LRF secretion during pubescence $(13,34)$. It would seem that before puberty the hypothalamic gonadostat is highly sensitive to negative feedback by sex steroids $(13,18)$; as a consequence of the diminished endogenous LRF secretion, there is little stimulation of the prepubertal LH-secreting gonadotropes and, hence, less readily releasable pituitary LH. With the onset of puberty and progression to adulthood, neural inhibition of LRF secretion is reduced as a result of decreasing sensitivity to gonadal steroid negative feedback $(13,18,21)$ so that pituitary gonadotropin synthesis and reserve increases. In addition, increased pituitary responsivity to LRF during puberty may be modulated by the rising levels of gonadal sex steroids.

The pathogenesis of idiopathic precocious puberty has not been elucidated, but the concept of precocious neural activation of the hypothalamic-pituitary-gonadal circuit has been advanced $(3,23,27)$. Increased endogenous synthesis and release of hypothalamic LRF could result from the premature maturation of the neural gonadostat, and increased pituitary LH and FSH synthesis and release would ensue secondarily. The mature pattern of LRF-induced LH release demonstrated in our study provides further support for the precocious activation of increased pituitary hormonal synthesis. Additional evidence for premature neural activation of the hypothalamic-pituitary gonadotropin system is the demonstration of a pubertal pattern of sleep-associated $\mathrm{LH}$ release in children with idiopathic precocious puberty (5).

In normal children, basal FSH levels rise dramatically between stages 1 and 2 of puberty in girls (38), in contrast to the greater LH rise during the same time period in boys (6). The rise in plasma estradiol which entrains is evidence of the importance of FSH in the initiation of ovarian steroid synthesis during early puberty. Additionally, LRF-induced FSH release is significantly greater in normal girls than boys at all stages of development $(13,34)$. As suggested previously, this increased FSH reserve may be a factor in the higher frequency of idiopathic precocious puberty in girls (13).

In the girls with idiopathic precocious puberty, the ovarian activation by endogenous gonadotropins may be an essential antecedent to the significant increase in plasma estradiol which followed the transient rise in plasma gonadotropins evoked by LRF. Three of the girls $(M S, R F$, and $K M)$, with significant increments in plasma estradiol and LRF-induced LH release, were the only ones who later exhibited vaginal bleeding during the 2-year study period. Hence, girls with premature matura-

Table 4. Clinical and hormonal data in patients with precocious thelarche and adrenarche ${ }^{1}$

\begin{tabular}{|c|c|c|c|c|c|c|c|c|c|c|c|c|}
\hline \multirow[b]{2}{*}{ Patients } & \multicolumn{2}{|c|}{ Age, yr } & \multicolumn{4}{|c|}{ Steroids } & \multicolumn{3}{|c|}{ LH } & \multicolumn{3}{|c|}{ FSH } \\
\hline & $\mathrm{CA}$ & BA & $\begin{array}{c}\mathrm{E}_{1}, \\
\mathrm{pg} / \mathrm{ml}\end{array}$ & $\begin{array}{c}\mathrm{E}_{2}, \\
\mathrm{pg} / \mathrm{ml}\end{array}$ & $\begin{array}{c}\mathrm{T}, \\
\mathrm{ng} / \mathrm{dl}\end{array}$ & $\begin{array}{c}\text { 17-OHP, } \\
\mathrm{ng} / \mathrm{ml}\end{array}$ & $\begin{array}{l}\text { Basal, } \\
\mathrm{ng} / \mathrm{ml}\end{array}$ & $\begin{array}{l}\text { Peak, } \\
\mathrm{ng} / \mathrm{ml}\end{array}$ & $\begin{array}{l}\text { Area, } \\
\text { units }\end{array}$ & $\begin{array}{l}\text { Basal, } \\
\mathrm{ng} / \mathrm{ml}\end{array}$ & $\begin{array}{l}\text { Peak, } \\
\text { ng/ml }\end{array}$ & $\begin{array}{l}\text { Area, } \\
\text { units }\end{array}$ \\
\hline \multicolumn{13}{|l|}{ Thelarche } \\
\hline$G H$ & $1-3 / 12$ & $1-3 / 12$ & 15 & 14 & & & 0.6 & 1.9 & 173 & 3.2 & 17.6 & 1,139 \\
\hline$G C$ & $1-9 / 12$ & 3 & 24 & 12 & & & 0.3 & 0.4 & 20 & 1.5 & 9.1 & 1,438 \\
\hline \multicolumn{13}{|l|}{ Adrenarche } \\
\hline$S G$ & $6-3 / 12$ & $7-10 / 12$ & 19 & 40 & & & 0.9 & 1.9 & 114 & 1.7 & 14.4 & 1,302 \\
\hline$S F$ & $8-8 / 12$ & $8-6 / 12$ & 56 & 141 & & & 0.9 & 2.0 & 108 & 2.0 & 6.5 & 760 \\
\hline Normal prepubertal value & & & $<15$ & $<100$ & & & & & & & & \\
\hline
\end{tabular}

\footnotetext{
${ }^{1}$ LH: luteinizing hormone; FSH: follicle-stimulating-hormone; CA: chronologic age; BA: bone age; $\mathrm{E}_{1}$ : estrone; $\mathrm{E}_{2}$ : estradiol in plasma; $\mathrm{T}$ :
} testosterone; 17-OHP: 17-hydroxyprogesterone 
Table 5. Effect of medroxyprogesterone acetate (MPA) therapy on basal steroid levels and on luteinizing hormone-releasing hormone-induced luteinizing hormone $(\mathrm{LH})$ and follicle-stimulating hormone (FSH) release

\begin{tabular}{|c|c|c|c|c|c|c|c|c|}
\hline \multirow[b]{2}{*}{ Patients } & \multirow{2}{*}{$\begin{array}{c}\text { MPA } \\
\text { therapy, } \\
\mathrm{mg} / 24 \mathrm{hr}\end{array}$} & \multicolumn{3}{|c|}{$\mathrm{LH}$} & \multicolumn{3}{|c|}{ FSH } & \multirow[b]{2}{*}{ Testosterone, $\mathrm{ng} / \mathrm{d}$} \\
\hline & & $\begin{array}{l}\text { Basal, } \\
\mathrm{ng} / \mathrm{ml}\end{array}$ & $\begin{array}{l}\text { Peak, } \\
\mathrm{ng} / \mathrm{ml}\end{array}$ & $\begin{array}{l}\text { Area, } \\
\text { units }\end{array}$ & $\begin{array}{l}\text { Basal, } \\
\mathrm{ng} / \mathrm{ml}\end{array}$ & $\begin{array}{l}\text { Peak, } \\
\mathrm{ng} / \mathrm{ml}\end{array}$ & $\begin{array}{l}\text { Area, } \\
\text { units }\end{array}$ & \\
\hline \multicolumn{9}{|l|}{ Males } \\
\hline \multirow[t]{3}{*}{$S M$} & & 1.9 & 8.4 & 1,000 & 1.3 & 1.8 & 60 & 385 \\
\hline & 20 & 0.9 & 2.5 & 227 & 0.8 & 1.3 & 86 & 19 \\
\hline & 40 & 0.9 & 2.3 & 184 & 0.8 & 0.9 & -13 & 7 \\
\hline$J P^{1}$ & & 0.7 & 6.7 & 958 & 3.2 & 8.3 & 1,193 & 62 \\
\hline \multirow[t]{2}{*}{$J P$} & & 1.7 & 10.7 & 1,048 & 3.6 & 13.2 & 1,720 & 270 \\
\hline & 20 & 1.7 & 7.4 & 690 & 2.4 & 5.9 & 662 & 36 \\
\hline \multicolumn{9}{|l|}{ Females } \\
\hline \multirow[t]{2}{*}{$K M$} & & 1.7 & 14.8 & 1,903 & 1.1 & 3.5 & 480 & 59 \\
\hline & 40 & 1.4 & 5.5 & 410 & 2.7 & 6.3 & 505 & 55 \\
\hline \multirow[t]{2}{*}{$J S$} & & 3.3 & 9.6 & 643 & 4.4 & 5.2 & 97 & 47 \\
\hline & 40 & 2.7 & 5.8 & 130 & 2.4 & 3.5 & 146 & 14 \\
\hline \multirow[t]{2}{*}{$K F$} & & 1.4 & 6.6 & 414 & 2.9 & 6.4 & 324 & 75 \\
\hline & 20 & 1.7 & 11.9 & 844 & 2.6 & 4.8 & 441 & 38 \\
\hline
\end{tabular}

${ }^{1}$ Patient with $\mathrm{CAH}$ and precocious puberty.

tion of the hypothalamic-pituitary gonadotropin axis, comparable to the adult female, have both greater pituitary gonadotropin reserve and enhanced ovarian steroidogenic responsiveness.

In the few girls studied with precocious adrenarche or thelarche, pituitary readily releasable LH was in the prepubertal range. In view of the predominant role of increased adrenal androgen synthesis (32), increased readily releasable LH was not expected in the girls with precocious adrenarche. In girls with precocious thelarche who had not progressed to true precocious puberty, a transient increase of LRF production, and thus of gonadotropin synthesis may lead to maturation of a limited number of graafian follicles. Increased ovarian estrogen production may occur only for a short period since gonadotropin stimulation usually is not sustained. Recent observations $(9,10)$ suggest that levels of plasma FSH in girls are higher during infancy than in later prepubertal years. This short term elevation of FSH production may predispose some girls to development of precocious thelarche. The tendency for greater FSH responses to LRF in these girls agrees with the findings of Job et al. (16). Normal girls in the first year of life tend to have greater amounts of readily releasable FSH (12). This observation may partially explain the data in the patients with precocious thelarche.

The significantly greater LRF-induced LH release in patients with precocious puberty than in premature thelarche or adrenarche suggests that the LRF test might have clinical utility in separating these entities, especially in early stages of development. The variable period between the onset of breast development and further progression of other pubertal manifestations in idiopathic precocious puberty $(27,39)$ make borderline responses such as that in our patient $A M$ (Table 4) difficult to interpret. Continuing clinical evaluation and sequential LRF testing may be needed in such cases.

MPA diminished the readily releasable $\mathrm{LH}$ in three of four patients with idiopathic precocious puberty and one with congenital adrenal hyperplasia who developed true precocious puberty. As in earlier studies in which urinary gonadotropins (30), gonadal steroid production (31), and clinical response to MPA $(17,29,37)$ were assessed, suppression of LRF-induced $\mathrm{LH}$ and FSH release was not uniform. Further evaluation of pituitary gonadotropin synthesis and release with LRF may contribute to our understanding of the variable clinical efficacy of MPA.
Previous studies have indicated that exogenous sex steroid administration may alter pituitary responsivity to LRF. When estradiol levels in plasma are raised either by a single intramuscular injection (40) or by a 12-hr infusion (19) of $17 \beta$-estradiol, both $\mathrm{LH}$ and $\mathrm{FSH}$ response to LRF are diminished. In contrast, treatment for 6 days with $17 \beta$-estradiol enhanced pituitary gonadotropin release after LRF (20). Treatment with combined estrogen and progesterone oral contraceptives lowers both readily releasable LH and FSH (11, 40). Short term progesterone treatment in humans also diminishes LRF-induced LH release (40). In several species, in vivo and in vitro studies support the notion that progesterone suppressed the release of pituitary gonadotropins by decreasing hypothalamic LRF release as well as by direct action on the pituitary gonadotropes $(7,8,22,36)$. The suppressive effects of MPA on pituitary gonadotropin release evoked by LRF may be at the level of the hypothalamus, the pituitary gland, or both.

\section{SUMMARY}

One hundred micrograms synthetic LRF was administered to children with idiopathic precocious puberty, precocious thelarche, precocious adrenarche, and to five patients with sexual precocity treated with MPA. The mean readily releasable $\mathrm{LH}$ rose to a significantly greater peak in the children with idiopathic precocious puberty than in normal prepubertal or pubertal children. The FSH responses, although higher, were not significantly greater in the children with precocious puberty than in normal subjects. Mean plasma estradiol rose significantly after LRF in the girls with precocious puberty. Readily releasable LH was in the prepubertal range in the children with incomplete sexual precocity. In four of five children with sexual precocity, treated with MPA, LRF-evoked LH release was diminished.

These data are compatible with the notion that premature neural activation of hypothalamic LRF synthesis occurs, leading to increased pituitary stores of $\mathrm{LH}$ in children with idiopathic precocious puberty.

\section{REFERENCES AND NOTES}

1. Amoss, M., Burgus, R., Blackwell, R., Vale, W., Fellows, R., and Guillemin, R.: Purification, amino acid composition and $\mathrm{N}$. 
terminus of the hypothalamic luteinizing hormone releasing factor (LRF) of ovine origin. Biochem. Biophys. Res. Commun., 44: 205 (1971).

2. Baker, B. L., Esken, R. A., and August, L. N.: Direct action of synthetic progestins on the hypophysis. Endocrinology, 92: 965 (1973).

3. Barnes, N. D., Cloutier, M. D., and Hayles, A. B.: The central nervous system and precocious puberty. In: M. M. Grumbach, G. D. Grave, F. Mayer: Control of the Onset of Puberty, p. 213 (John Wiley and Sons, New York, 1974).

4. Blackwell, R. E., and Guillemin, R.: Hypothalamic control of adenohypophysial secretions. Ann. Rev. Physiol., 35: 357 (1973).

5. Boyar, R. M., Finkelstein, J. M., David, R., Roffwarg, H., Kapen, S., Weitzman, E. D., and Hellman, L.: Twenty-four hour patterns of plasma luteinizing hormone and follicle stimulating hormone in sexual precocity. New Engl. J. Med., 289: 282 (1973).

6. Burr, I. M., Sizonenko, P. C., Kaplan, S. L., and Grumbach, M. M.: Hormonal changes in puberty. I. Correlation of serum luteinizing hormone and follicle stimulating hormone with stages of puberty, testicular size, and bone age in normal boys. Pediat. Res., 4: 25 (1970).

7. Cumming, I. A., Buckmaster, J. M., Cerini, J. C., Cerini, M. E., Chamley, W. A., Findlay, J. K., and Goding, J. R.: Effect of progesterone on the release of luteinizing hormone induced by a synthetic gonadotrophin releasing factor in the ewe. Neuroendocrinology, 10: 338 (1972).

8. Debeljuk, L., Arimura, A., and Schally, A. V.: Effect of estradiol and progesterone on the LH-release induced by LH-releasing hormone (LH-RH) in intact diestrous rats and anestrous ewes. Proc. Soc. Exp. Med., 139: 774 (1972).

9. Faiman, C., and Winter, J. S. D.: Sex differences on gonadotrophin concentration in infancy. Nature, 232: 130 (1971).

10. Forest, M. G., Sizonenko, P. C., Cathiard, R. M., and Bertrand, J.: Hypophysogonadal function in humans during the first year of life. J. Clin. Invest., 53: 819 (1974).

11. Franchimont, P., Becker, H., Ernould, C., Thys, C., Demoulin, A., Bourguignon, J. P., Legros, J. J., and Valcke, J. C.: The effect of hypothalamic luteinizing hormone releasing hormone (LH-RH) on plasma gonadotrophin levels in normal subjects. Clin. Endocrinol., 3: 27 (1974).

12. Garnier, P. E., Chaussain, J. L., Binet, E., Schlumberger, A., and Job, J. C.: Effect of synthetic luteinizing hormone releasing hormone ( $\mathrm{LH}-\mathrm{RH})$ on the release of gonadotropins in children and adolescents. V. Relation to age, sex, and puberty. Acta Endocrinologica, in press.

13. Grumbach, M. M., Roth, J. C., Kaplan, S. L., and Kelch, R. P.: Hypothalamic-pituitary regulation of puberty: Evidence and concepts derived from clinical research. In: M. M. Grumbach, G. D. Grave, and F. Mayer: The Control of the Onset of Puberty, p. 115 (John Wiley and Sons, New York, 1974).

14. Jenner, M. R., Kelch, R. P., Kaplan, S. L., and Grumbach, M. M. Hormonal changes in puberty. IV. Plasma estradiol, LH, and FSH in prepubertal children, pubertal females, and in precocious puberty, premature thelarche, hypogonadism, and in a child with a feminizing ovarian tumor. J. Clin. Endocrinol., 34: 521 (1972).

15. Job, J. C., Garnier, P. E., Chaussain, J. L., Binet, E., Rivaille, P., and Milhaud, G.: Effects of synthetic luteinizing hormone-releasing hormone (LH-RH) on serum gonadotropins ( $\mathrm{LH}$ and $\mathrm{FSH}$ ) in normal children and adults. Rev. Eur. Etudes Clin. Biol., 17: 411 (1972).

16. Job, J. C., Garnier, P. E., Chaussain, J. L., and Canlorbe, P.: Effect of synthetic luteinizing hormone-releasing hormone ( $\mathrm{LH}-\mathrm{RH})$ on the release of gonadotropins in hypophyso-gonadal disorders of children and adolescents. II. Precocious puberty and premature thelarche. Biomedicine, 19: 77 (1973).

17. Kaplan, S. A., Ling, S. M., and Irani, N. G.: Idiopathic isosexual precocity: therapy with medroxyprogesterone. Amer. J. Dis. Child., 116: 591 (1968).

18. Kelch, R. P., Kaplan, S. L., and Grumbach, M. M.: Suppression of urinary and plasma follicle-stimulating hormone by exogenous estrogens in prepubertal and pubertal children. J. Clin. Invest., 52: 1122 (1973).

19. Keye, W. R., Jr., and Jaffe, R. B.: Modulation of pituitary gonadotropin response to gonadotropin releasing hormone by estradiol. J. Clin. Endocrinol. Metab., 38: 805 (1974).

20. Keye, W. R., Jr., and Jaffe, R. B.: Modulation of pituitary responsiveness to gonadotropin releasing hormone $(\mathrm{GnRH})$ in women. Proceedings of the Endocrine Society, Atlanta, June (1974).

21. Kulin, H. E., and Reiter, E. O.: Gonadotropin suppression by low dose estrogen in men: evidence for differential effects upon FSH and LH. J. Clin. Endocrinol. Metab., 35: 836 (1972).

22. Libertun, C., Cooper, K. J., Fawcett, C. P., and McCann, S. M.: Effects of ovariectomy and steroid treatment on hypophysea sensitivity to purified LH-releasing factor (LRF). Endocrinology, 94: $518(1972)$.

23. Liu, N., Grumbach, M. M., de Napoli, R. A., and Morishima, A. The prevalence of electroencephalographic abnormalities in idiopathic precocious puberty and premature pubarche: Bearing on pathogenesis and neuroendocrine regulation of puberty. J. Clin. Endocrinol. Metab., 25: 1296 (1965).

24. Marshall, W. A., and Tanner, J. M.: Variations in pattern of pubertal changes in girls. Arch. Dis. Childhood, 44: 291 (1969).

25. Marshall, W. A., and Tanner, J. M.: Variations in the pattern of pubertal changes in boys. Arch. Dis. Childhood, 45: 13 (1970).

26. Monahan, M., Rivier, J., Burgus, R., Amoss, M., Blackwell, R., Vale, W., and Guillemin, R.: Synthese totale par phase solide d'un decapeptide qui stimule la secretion des gonadotropines hypophysaires LH et FSH. C. R. Acad. Sci. (Paris), 273: 508 (1971).

27. Reiter, E. O., and Kulin, H. E.: Sexual maturation in the female: normal development and precocious puberty. Pediat. Clin. N. Amer., 19: 581 (1972).

28. Reiter, E. O., Kaplan, S. L., Conte, F. A., and Grumbach, M. M.: The pituitary response to LRF in children with congenital virilizing adrenal hyperplasia. In preparation.

29. Richman, R. A., Underwood, L. E., French, F, S., and Van Wyk, J. J.: Adverse effects of large doses of medroxyprogesterone acetate (MPA) in idiopathic isosexual precocity. J. Pediat., 79: 963 (1971).

30. Rifkind, A. B., Kulin, H. E., Cargille, C. M., Rayford, P. C., and Ross, G. T.: Suppression of urinary excretion of luteinizing hormone $(\mathrm{LH})$ and follicle stimulating hormone (FSH) by medroxyprogesterone acetate. J. Clin. Endocrinol. Metab., 29: 506 (1969).

31. Rivarola, M. A., Camacho, A. M., and Migeon, C. J.: Effect of treatment with medroxyprogesterone acetate (Provera) on testicular function. J. Clin. Endocrinol. Metab., 28: 679 (1968).

32. Rosenfield, R. L.: Plasma 17-ketosteroids and 17- $\beta$ hydroxysteroids in girls with premature development of sexual hair. J. Pediat., 79: 260 (1971).

33. Roth, J. C., Grumbach, M. M., and Kaplan, S. L.: Effect of synthetic luteinizing hormone-releasing factor on serum testosterone and gonadotropin in prepubertal and adult males. J. Clin. Endocrinol. Metab., 37: 680 (1973).

34. Roth, J. C., Kelch, R. P., Kaplan, S. L., and Grumbach, M. M.: FSH and LH response to luteinizing hormone-releasing factor in prepubertal and pubertal children, adult males and patients with hypogonadotropic and hypergonadotropic hypogonadism. J. Clin. Endocrinol. Metab., 35: 926 (1972).

35. Schally, A. V., Arimura, A., and Kastin, A. J.: Hypothalamic regulatory hormones. Science, 179: 341 (1973).

36. Schally, A. V., Redding, T. W., and Arimura, A.: Effect of sex steroids on pituitary responses to $\mathrm{LH}$ and $\mathrm{FSH}$ releasing hormone in vitro. Endocrinology, 93: 893 (1973).

37. Schoen, E. J.: Treatment of idiopathic precocious puberty in boys. J. Clin. Endocrinol. Metab., 26: 363 (1966).

38. Sizonenko, P. C., Burr, I. M., Kaplan, S. L., and Grumbach, M. M. Hormonal changes in puberty. II. Correlation of serum luteinizing hormone and follicle stimulating hormone with stages of puberty and bone age in normal girls. Pediat. Res., 4: 36 (1970).

39. Thamdrup, E.: Precocious Sexual Development. (Charles C Thomas, Springfield, Ill., 1961).

40. Thompson, I. E., Arfania, J., and Taymor, M. L.: Effects of estrogen and progesterone on pituitary response to stimulation by luteinizing hormone releasing factor. J. Clin. Endocrinol. Metab., 37: 152 (1973).

41. We thank the National Pituitary Agency and the National Institute of Arthritis and Metabolic Disease for the purified hormones used in this study. We are grateful to Dr. R. Guillemin, Salk Institute, for generously supplying synthetic LRF. Appreciation is also expressed to A. Jardiolin, S. Waters, and the physicians and nurses of the Pediatric Clinical Research Center.

42. Presented in part at the American Pediatric Society, Washington, D.C., May 1974.

43. Dr. Reiter is a trainee in Pediatric Endocrinology under a program sponsored by the National Institute of Arthritis, Metabolism and Digestive Diseases, United States Public Health Service, National Institutes of Health

44. This work was supported in part by grants from the National Institute of Child Health and Human Development and the National Institute of Arthritis, Metabolism and Digestive Diseases, United States Public Health Service, National Institutes of Institutes of Health.

45. Requests for reprints should be addressed to: M. M. Grumbach, M.D., Department of Pediatrics, University of California San Francisco, San Francisco, Calif. 94143 (USA).

46. Accepted for publication October 3, 1974 